\title{
VÁROSMARKETING MINT A HELYI GAZDASÁGFEJLESZTÉS EGYIK LEHETSÉGES ESZKÖZE *
}

\author{
(City marketing as one of the possible tools of local economic \\ development) \\ KOZMA GÁBOR
}

A városmarketing elméleti alapjai

\section{A városmarketing kialakulása}

A városmarketing - mint a várospolitika újfajta, piacközpontú megközelítése - az 1970-es évek második felétől került előtérbe a nyugat-európai és észak-amerikai országokban, majd a rendszerváltozás után a közép-európai országok önkormányzatai is egyre nagyobb figyelmet szenteltek ennek a témának. Az elnevezéssel kapcsolatban - városmarketing - le kell szögezni, hogy ilyen jellegü tevékenységet nem csak városok folytathatnak, hanem kisebb (pl. községek) és nagyobb (pl. megyék) közigazgatási egységek is. Az angol nyelvben összefoglaló kifejezésként a ,place-marketing" meghatározást használjak (a témával foglalkozó könyvek jelentős részének a címében is ez szerepel - lásd például Kotler, P. et al. 1993, Philo, C. és Kearns, K. 1993), és ennek csak egy részét alkotja a városmarketing (city-marketing - lásd 1 . ábra). Dolgozatomban elsósorban a városokra koncentrálok, de megállapításaim kisebb-nagyobb megszorításokkal igazak a községekre és a megyékre is.

Az önkormányzatok ilyen irányú tevékenységének a fejlỏdése mögött azok a nyugat- és közép-európai, illetve észak-amerikai gazdasági és politikai változások állnak, amelyek jelentősen megrengették a városok gazdasági alapjait (Ashworth, G. J.-Voogd, H. 1990, Berg, L. van den et al. 1990, Parkinson, M.1991, Kotler, K. et al. 1993). Egyrészt az 1970-es és 1980-as évek gazdasági szerkezetváltása (a szolgáltató szektor szerepének növekedése - a deindusztrializáció jelensége) jelentős kihívást jelentett számukra, amire valamilyen módon reagálniuk kellett. Az új viszonyok egyebek mellett alapvetően meg-

\footnotetext{
*A dolgozat elkészítését az F 012854 és a W 015339 számú OTKA-pályázatok támogatták.
} 


\section{1. ÁBRA}

A városmarketing helye a ,place-marketingen" belül

(The situation of city marketing within ",place-marketing”)

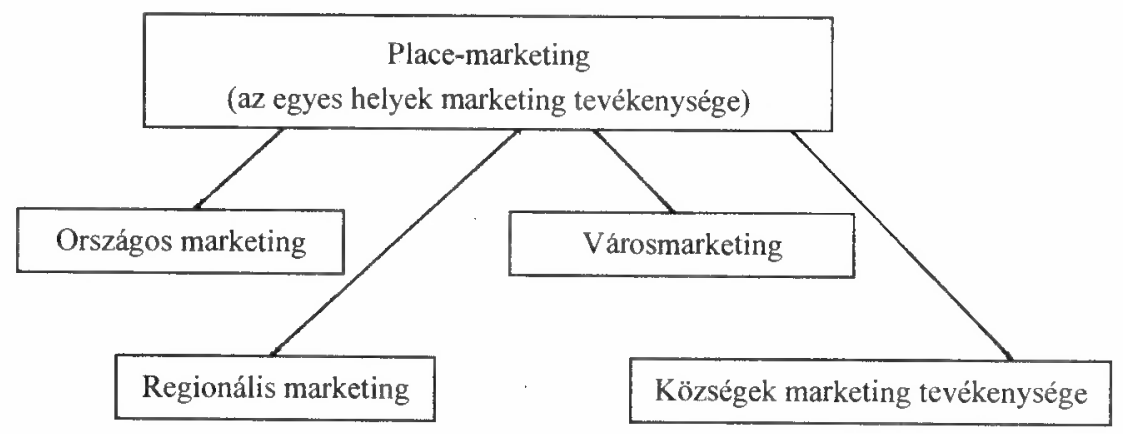

Szerkesztette: Kozma G.

változtatták az egyes telepítőtényezők fontosságát: a jól képzett munkaerő szerepének növekedésével párhuzamosan a telepítőtényezök között egyre nagyobb figyelmet kaptak a kulturális kikapcsolódási lehetőségek, à vonzó természeti környezet. Az átalakulás a legdrámaibb a leromlott iparvidékek településeiben volt, amelyeknek eredeti gazdasági bázisuk szinte teljes elvesztése után új tevékenységeket kellett vonzaniuk.

Másrészt az 1980-as évek elejétől mind több ország költségvetésének kellett jelentős finanszírozási problémákkal szembenéznie, és így nem volt képes elegendő támogatást nyújtani az önkormányzatoknak. Ennek következtében a településeknek saját erőforrásaikra kellett támaszkodniuk, ami a piaci környezet fokozattabb vizsgálatát tette szükségessé.

Harmadrészt az 1970-es évek második felében a fejlett világ egyre több országában döbbentek rá arra, hogy az 1945 után kifejlödött, központilag irányított területi tervezés nem képes hatékonyan megoldani a felmerült problémákat. Ez a felismerés csökkentette a bizalmat a hagyományos tervezési módszerek iránt és azt eredményezte, hogy az önkormányzatok fogékonyabbá váltak az új megközelítési módok iránt. Ennek részeként Nyugat-Európa legtöbb országában az 1980-as évek elejétől kezdve egy decentralizációs tendenciát lehetett megfigyelni. Fokozatosan megváltozott a központi vezetés és a helyi önkormányzatok viszonya, folyamatosan nött az utóbbiak szerepe és felelössége a helyi ügyek intézésében, és ezzel párhuzamosan növekvő befolyásra tettek szert a nemzetek feletti (pl. a határ két oldalán fekvö városok, megyék közötti) együttmüködés különböző formái.

Negyedrészt az 1980-as évek gyors technikai változásai (a telekommunikációs technológia és a közlekedés fejlődése és költségeinek csökkenése) és az 1990-es évtized politikai eseményei (a hidegháború vége, az egységes Európa kialakulása) az áruk, szolgáltatások, új technológiák és a tóke országok közötti áramlásának a gyorsulását idézték elö. 
Emellett maguk után vonták a kereskedelem, a beruházások és a munkaerőpiac globalizálódását, valamint a vállalatok közötti verseny éleződését: mindazon cégek, amelyek nem a megközelitőleg optimális telephelyen múködnek, veszteséget kénytelenek elkönyvelni, és ez elöbb-utóbb a cég bezárásához vagy áttelepítéséhez vezet. Ennek hatására napjainkban a tér és az idö összezsugorodását lehet megfigyelni: a nemzetek közötti versenyt egyre inkább felváltja a városok és a régiók közötti vetélkedés, a helyi vezetésnek pedig rendkívül gyorsan kell reagálni a változó világ új és új kihívásaira (pl. gyors intézkedésekkel kell megakadályozni a helyi cégek távozását).

Mindezen változások következtében az önkormányzatok számára nyilvánvalóvá vált, hogy a szolgáltatások és az infrastruktúra-fejlesztés területén hosszú ideig betöltött paszszív szerepük tovább nem tarható fenn, és a későbbiekben sokkal kezdeményezöbb szerepet kell játszaniuk a fejlödési folyamatban. Nem elég ellenőrizni a fejlödést, de hatékonyan támogatni is kell azt. Ez a felismerés fokozatosan aktívabb, vállalkozóbb szellemủ önkormảnyzatok kialakulását idézte elő.

Hangsúlyozni kell, hogy ez a tevékenység vagy legalábbis egyes részei, nem teljesen ismeretlen elemei a várospolitikának. A második világháború után sok helyi önkormányzat tett kísérletet arra, hogy új épületek felépitésével, az infrastruktúra és a szolgáltatások fejlesztésével növelje a település vonzerejét, másrészt (elsősorban a turizmus vonatkozásában) a települések és régiók reklámtevékenységének is igen jelentós hagyományai vannak. Az utóbbi tény hatása olyan erős volt, hogy a városmarketing (city-marketing) és városreklámozás (city-promotion) kifejezések hosszú ideig azonos jelentéssel bírtak, és a városmarketinggel foglalkozó publikációk csaknem kizárólag a reklámtevékenységre koncentráltak (pl. Burgess, J. A. 1982, Bartels, C. P. A.-Timmer, M. 1987).

$A$ városmarketing szélesebb értelmezése csak az 1980-as évek végén nyert teret, és azóta a témával foglalkozó elméleti könyvek (pl. Ashworth, G. J.-Voogd, H. 1990, Philo, C.- Kearns, K. 1993, Kotler, $P$. et al. 1993) illetve az esettanulmányokat bemutató cikkek (pl. Madsen, H. 1992, Paddison, R. 1992, Short, J. R. et al. 1993) egyre több tevékenységet vesznek figyelembe. A szerzök a városmarketinget egy olyan módszerként definiálják, amelyet a települések arra tudnak felhasználni, hogy jovitsák versenyképességüket a piacon. Hangsúlyozzák, hogy ez a tevékenység több összetevőbool áll és bármelyik elem kihagyása veszélybe sodorhatja az egész folyamat sikerét.

$\mathrm{Az}$ önkormányzatok marketing tevékenysége a magyar kutatók érdeklődését is felkeltette. Az 1990-es évek eleje óta több hazai cikk és tanulmány is foglalkozott ezzel a témával (pl. Ats Z. 1994, Fülöp, G. 1994, Probáld K. 1994, Schmidt L. 1994).

\section{A városmarketing sajátosságai}

A hagyományos marketing és a városmarketing között jelentős eltérések vannak, amiért az utóbbi sokkal bonyolultabb és kifinomultabb megközelítést igényel. Ezek a különbségek elsősorban az „eladandó termék” vonatkozásában figyelhetők meg: a település mint termék más tulajdonságokkal rendelkezik mint azon árucikkek és szolgáltatások, amelyek 
eladásával a marketingtudomány kezdettöl fogva foglalkozik (Ashworth, G. J.-Voogd, H. 1990, Berg, L. van den et al. 1990).

A városmarketing során egyrészt a termék sokkal komplexebb, ami azt jelenti, hogy ugyanazt a fizikai teret kell eladni egyidejüleg különböző „,fogyasztóknak”, akik más és más célra akarják azt felhasználni. A belvárost a turista például úgy szemléli mint történelmi látványosságot, a helyi lakos mint a lakóhelyét, vagy mint egy bevásárlóközpontot, a vállalkozó pedig elsősorban az üzleti lehetőségeket keresi (Ashworth, G. J.-Voogd, $H$. 1988). A belváros mint termék térbelileg azonban nem tágítható ki, és ennek következtében szinte lehetetlen mindenki számára megfelelö megoldást találni. Igen nagy az egyes fogyasztók közötti konfliktus valószínüsége.

Másrészt a tradicionális adás-vétellel szemben a városok „eladása" nem vonja maga után a tulajdonjog átruházását, és nem idézi elỏ a városi szolgáltatások feletti rendelkezési jog átadását sem.

Harmadrészt a városok sajátos térbeli környezetben, hierarchiában helyezkednek el. Ez a tény jelentösen befolyásolja marketing tevékenységüket. Igen nagy a valószínüsége például annak, hogy a vásárló (pl. a turista) nem ugyanazt a teret akarja megvenni, mint amit az eladó el akar neki adni. Ez azt jelenti, hogy a marketing tevékenység elsősorban arra a területre korlátozódik, amelynek irányítása az önkormányzat, illetve más szervezetek (pl. idegenforgalmi hivatal, kereskedelmi kamara) hatáskörébe tartozik (pl. város vagy megye), ugyanakkor semmilyen garancia nincs arra, hogy ez megfelel annak a területnek, amit a vásárló meg akar venni. Ennek elkerülése érdekében Hollandia három északi provinciájának - Groningen, Friesland és Drenthe - idegenforgalmi hivatalai közösen, egy prospektust használva vesznek részt a különböző nemzetközi utazási vásárokon. A szakemberek ugyanis tisztában vannak azzal, hogy a külföldi turisták valószínúleg nem az egyes provinciák, hanem Észak-Hollandia iránt érdeklődnek.

A marketing tevékenység során emellett figyelembe kell venni az ún. „shadow-hatást” (területi árnyékolást) is. Ez azt takarja, hogy egy város marketing tevékenységét jelentösen befolyásolja a környezetében fekvő más települések illetve a nagyobb közigazgatási egységek (pl. a megye, esetleg az ország) munkája, amely lehet jobb, rosszabb, vagy esetleg teljesen más témára irányuló. Hollandiában például az országos idegenforgalmi hivatal elsősorban a „Netherlands-Waterland" témára - mint alapvető turistatermékre összpontosítja a figyelmét, ez azonban alig segíti az olyan történelmi városok, mint például Groningen munkáját (Ashworth, G. J.-Voogd, H. 1994a). Ebben az esetben a városnak arra kell törekednie, hogy részesedjen a pozitív shadow-hatásból és távol tartsa magát a negatívtól.

Negyedrészt a város - mint eladandó termék - esetében hiányzik az a rugalmasság, amellyel az egyes árucikkek és szolgáltatások rendelkeznek: a települést nehezen lehet a létező, illetve potenciális „fogyasztók” igényeinek megfelelóen átalakítani, a változás jelentőss pénzösszegeket és igen hosszú idöt igényel. Szemben a tradicionális árucikkekkel a város mint termék helyhez kötött, a maga teljes valóságában bemutatni csak az adott helyszínen lehet. Ennek következtében a telepullés elönyös tulajdonságait több esetben csupán 
bizonyos közvetítő eszközök (pl. színes kiadványok, különbözö szervezetek) révén terjesztheti (Probáld K 1994).

Emellett sajátos helyzetet (és gyakran problémát) eredményez az a tény, hogy a városok marketing tevékenységének elsődleges irányítóit, a helyi önkormányzatokat elsösorban politikai megfontolások vezetik. Ennek következményeként gyakran rövid távú (a választási periódus ideje alatt sikert hozó) célok elérésére törekednek, másrészt a választások eredményeként a vezető tisztségekben bekövetkezö esetleges váltás olyan drasztikus törést okozhat a politikában, amely nem segíti a folyamatosságot elönyben részesítő magánszektor beruházásait.

\section{A városmarketing szakaszai}

A városmarketing - mint már korábban említettem - több összetevőböl áll, és bármelyik elem kihagyása az egész folyamat sikerét veszélyeztetheti (2. ábra). Legalább ilyen fontos, hogy az önkormányzat a marketing tevékenység megkezdése elött széles körü tervet készitsen, és ebben részletezze az egyes elemekkel (összetevőkkel) kapcsolatban felmerülö legfontosabb kérdéseket: ki felelös az adott tevékenységért, hogyan hajtják végre az adott tevékenységet, mennyibe fog kerülni és mikorra várható a befejezése (Kotler, P. et al. 1993). Egy ilyen terv lehetővé teszi a hatáskörök és feladatok pontos elosztását és a terv végrehajtásának ellenörzését.

\section{2. ÁBRA}

A városmarketing egyes elemei és egymáshoz való viszonyuk (The individual elements of city marketing and their relationship)

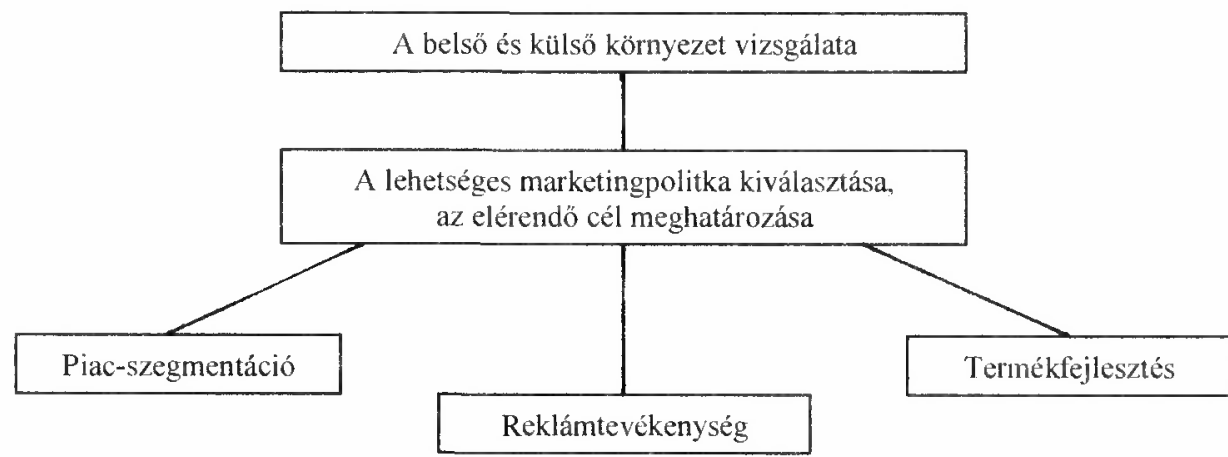

Szerkesztette: Kozma G. 
A belsö és külsö környezet vizsgálata

Az első igen fontos feladat a települések belsó és külső környezetének az elemzése, amelyet az angol strengths - erös pontok, weaknesses - gyenge pontok, opportunities lehetöségek, threaths - veszélyek szavak alapján SWOT-elemzésnek is neveznek.

A kutatás keretében egyrészt meg kell vizsgálni azokat a helyi adottságokat (erős pontokat illetve hiányosságokat), amelyeknek a fejlődését az önkormányzat - bizonyos határok között - képes befolyásolni. Idetartoznak a környezeti problémák, az infrastruktúra állapota (pl. az egészségügyi ellátás, a szállodai kapacitás, az üzlethálózat fejlettsége stb.), a kikapcsolódási lehetőségek, a közbiztonság helyzete stb.

A belsö környezet vizsgálata során igen fontos az adott településröl az emberek körében kialakult vélemények feltárása. Ez elkerülhetetlen, mivel majdnem minden piaci szereplö az érzelmek, elvárások és információk hatalmas tárházával rendelkezik függetlenül attól, hogy korábban meglátogatta-e az adott helyet, vagy nem. Beszélgetnek olyan emberekkel, akik már voltak az adott városban, híreket hallgatnak, újságcikkeket olvasnak az ott zajló eseményekröl és az így kialakult benyomások jelentősen befolyásolják tevékenységüket.

A városmarketing során figyelembe kell venni a már létezö információkàt. Törekedni kell a meglévő pozitiv érzelmek megerósítésére és a negativ - vagy legalábbis ellentmondásos benyomások - megsemmisítésére, hatásuk csökkentésére.

A vizsgálat után igen fontos összehasonlítani az adott településhez kapcsolódó érzelmeket és benyomásokat a tényleges adottságokkal, és ez az elemzés legalább három különbözö helyzetet eredményezhet (Ashworth, G. J.-Voogd, H. 1994b);

- ha a benyomások jobbak, mint a település adottságai, a legfontosabb feladat a termékfejlesztés, és egy elfogadható fejlettségi szint eléréséig a hiányosságok eltitkolása;

- abban az esetben, ha az adottságok jobbak, mint a létező benyomások, a kedvezötlen vélemények megváltoztatása érdekében az önkormányzatnak egy intenzív reklámkampányba kell kezdenie;

- ha a terület jó adottságokkal és kedvező képpel rendelkezik, a legfontosabb feladat ezen helyzet fenntartása.

Továbbá elemezni kell a külsö környezetet, fel kell tárni azokat a lehetőségeket és veszélyeket is magukba foglaló folyamatokat, amelyek befolyásolása kivül esik a helyi önkormányzat hatáskörén. Ennek keretében meg kell állapítani a központi kormányzat területi politikájának legfontosabb elemeit és jövöbeli irányait, az országos és nemzetközi fejlödés jelenlegi és potenciális trendjeit. Igen fontos megvizsgálni a fogyasztói magatartásban várható változásokat ( $\mathrm{pl}$. növekvő figyelem a környezeti problémáknak és az életminőségnek), valamint a jelenlegi és jövőbeli vetélytársakat: mely területeken rendelkeznek jobb illetve rosszabb adottságokkal, mely területekre koncentrálják elsősorban a figyelmüket stb. A külső környezet elemzése során a lehetöségeket és veszélyeket különböző szempontok alapján kell értékelni. Vizsgálni kell, mekkora az esélye a megvalósulásuknak, és fel kell tárni, hogy realizálódásuk esetén mekkora hasznot illetve kárt okozhatnak a településnek. 
A SWOT-elemzés eredményei igen lényeges bázisát képezik az önkormányzat jövőbeli politikájának. Segítségével az önkormányzat olyan széles körü képet kaphat a terület helyzetéről, amely hozzájárulhat a legnagyobb sikert ígérő marketingpolitika kiválasztásához és ezen belül azon célok kijelöléséhez, ahol adottak a fejlődés feltételei. Ennek során azonban arra kell törekedni, hogy a város egy megkülönböztetö képet alakitson ki magáról: világossá kell tenni, miért előnyös ezen település kiválasztása, mi emeli ki a vetélytársak közül.

\section{A termékfejlesztés}

A belső és külső környezet elemzésével párhuzamosan az önkormányzatoknak figyelmet kell fordítaniuk adottságaik fejlesztésére. Ez négy területet foglal magába: biztosítani kell a fejlödés infrastrukturális alapjait, megfelelő együttmúködést kell létrehozni a marketing tevékenységgel foglalkozó különböző szervezetek között, ki kell alakítani egy vonzó városképet és olyan látványosságokat kell teremteni, amelyek képesek a városba csábítani a látogatókat. Az elsö két tényezö mindenfajta továbblépés elöfeltételét képezi, az utóbbi kettő (amelyek igen szoros kapcsolatban állnak egymással) pedig olyan egyedi jelleget ad a településnek, amely elösegíti kiemelkedését a vetélytársak sorából.

$\mathrm{Az}$ infrastruktúra-fejlesztés területén az egyik legfontosabb feladat a település elérhetöségének a javítása. Ennek során a legelönyösebb a légi összeköttetés biztosítása (elsősorban az Amerikai Egyesült Államokban), valamint a kiváló vasúti és közúti kapcsolat megteremtése. Emellett törekedni kell az adott városban elérhetö életszínvonal állandó javítására: olyan lakókörnyezetet, kikapcsolódási lehetőségeket, oktatási feltételeket stb. kell biztosítani, amelyek megfelelnek a jól képzett, magas jövedelmủ rétegek igényeinek is.

Mint már említettem az önkormányzaton kívül sok egyéb (gyakran nem állami) szervezet (pl. turistaügynökségek) is foglalkozik marketing tevékenységgel. Ennek következtében a hatékony marketing alapja a közös munka: a különbözö szereplöknek tudniuk kell egymásról, egymás tevékenységének föbb irányairól, megegyezésre kell jutniuk a hosszú távú célokról és a követendỏ stratégiáról (Parkinson, M. 1991), valamint az önkormányzatoknak elő kell segíteniük a magánszektor befektetéseit. Ez a közös munka (angol elnevezéssel public-private partnership) különböző formákat ölthet: a szereplök létrehozhatnak egy új - az eltérỏ tevékenységeket koordináló - szervezetet, dokumentumban fektethetik le az együttmüködés alapjait, rendszeres idöközönként megbeszéléseket folytathatnak a felmerült gondokról. Az ilyen együttmúködés kialakítása elkerülhetetlen, mivel nyugat-európai példák azt mutatják, hogy az 1980-as évek második felében a problémákkal eredményesen megküzdő városok (pl. Hamburg, Rotterdam, Montpellier) sikerének egyik alapját a különbözö szektorok közötti szövetség képezte (Parkinson, M. 1991).

A sajátos arculatot biztosító városkép megteremtése során két szélsö esetet lehet megkülönböztetni, amelyek között számos átmenet létezik. Egyfelöl a jelentős múemlékekkel rendelkezö városoknak (elsósorban a kontinentális Európában) történelmi hangulatot 
árasztó városkép kialakitására kell törekedniük: el kell érniük, hogy a látogatók tényleg érezzék a hely történelmi szellemét. Ezzel szemben a múlttal gyökeresen szakítani kívánó településeknek (pl. az Amerikai Egyesült Államok és Nagy-Britannia ipari térségeinek városai) megújulásukat a városképben is éreztetniük kell. Modern épületek, színházak, kongresszusi központok stb. felépítésével kell hangsúlyozniuk a múlttal történö teljes szembefordulást, azt hogy a város képes megfelelni az új, megváltozott követelményeknek.

Jó lehetőséget jelent a vetélytársak közül történỏ kiemelkedésre, ha a település rendelkezik olyan látványosságokkal, amelyek képesek vonzani a látogatókat. Ezt a szerepet betölthetik természeti szépségek, mint a Niagara-vízesés, a Grand-kanyon, emellett a városok profitálhatnak olyan világhírú történelmi épületek jelenlétéböl, mint a párizsi Eiffel-torony, az athéni Akropolisz stb. A települések jelentös része azonban nem rendelkezik ilyen nevezetességekkel, ezért az önkormányzatoknak új látványosságok megteremtésére kell törekedniük.

Ennek érdekében az önkormányzatok elsỏsorban két területre koncentrálhatnak. Egyrészt ủj létesítményeket kell építeniük (pl. kiállítási központok, múzeumok), másrészt törekedniük kell különbözỏ kulturális események megszervezésére (pl. fesztiválok, kiállítások, sportesemények). Ebből a szempontból napjainkban a legambiciózusabbak az egykori iparvidékek városai, amelyek - a deindusztrializáció káros következményeitől (a munkanélküliség emelkedése, elhagyott ipartelepek) szenvedve - ezekben az új nevezetességekben látják a felemelkedés egyik lehetöségét (Law, C. H. 1992).

A látványosságok több szempontból is támogatják a település fejlódését (Karski, H. 1990, Law, C. H. 1992, Lim, H. 1993). Hozzájárulnak új munkahelyek teremtéséhez és az országos sajtóban publicitást biztosítanak a városnak. Elösegitik, hogy a településröl egy dinamikus és vonzó kép alakuljon ki, és támogatják az életszínvonal növekedését. Ezek a tényezök igen lényegesek, mivel mindazok a területek, amelyeket a külső szereplök érdekes helynek tartanak, jobb adottságokkal rendelkeznek az erős kulturális preferenciát felmutató, jól fizetett, magas szakképzettségü rétegek csábításában, és ezáltal a legmodernebb gazdasági ágazatok letelepítésében. A látványosságok a helyi lakosság körében elösegítik a helyi öntudat és büszkeség megerősödését, és a városközpont felélesztésével javítják a városlakók biztonságérzetét.

\section{A piac-szegmentáció}

A városmarketing következỏ igen fontos eleme a piac vizsgálata és annak eldöntése, kiket akar az önkormányzat vonzani. Ennek keretében három különböző piac-szegmentációs stratégia között lehet választani, amelyek elönyökkel és hátrányokkal egyaránt rendelkeznek.

Differenciálatlan szegmentációs stratégia esetén az önkormányzat nem veszi figyelembe a potenciális fogyasztók közötti különbségeket, az egyes csoportokat azonos mó- 
don kezeli és olyan stratégiát folytat, amely a legszélesebb rétegek figyelmének a felkeltésére alkalmas. Ez a megközelités alacsonyabb kiadásokkal jár (pl. nem kell részletes piackutatást folytatni), de magában hordozza annak veszélyét, hogy a település egy célcsoporton belül sem tud szilárd pozícióra szert tenni.

A differenciált szegmentációs stratégia során az önkormányzat már kiválaszt bizonyos célcsoportokat és elsösorban rájuk fordít nagyobb figyelmet. Ez alkalmas arra, hogy a város az egyès célcsoportokon belül jelentösen megerösítse helyzetét, ugyanakkor a költségek nagymértékü emelkedését vonja maga után (pl. az egyes célcsoportok számára speciális létesítményeket kell kialakítani, más-más reklámkampányt kell folytatni).

A koncentrált szegmentációs stratégia keretében az önkormányzat csak egy-két célcsoportra koncentrál és ezeket próbálja meg a településre csábítani. A célcsoportok jó kiválasztása esetén ez a stratégia jelentős sikerrel járhat, ugyanakkor ebben az esetben a legnagyobb a kudarc lehetősége is. A külső környezetben bekövetkezett hirtelen változások (pl. új vetélytárs feltủnése, a célcsoportok igényeinek gyors változása, váratlan politikai események) veszélybe sodorhatják az egész marketingpolitika jövőjét.

Az önkormányzat által követendỏ politikát több tényező is befolyásolja, amelyek közül a legfontosabbak a rendelkezésre álló anyagi eszközök, a terület adottságai és a vetélytársak tevékenysége. A jelentős anyagi erőforrásokkal rendelkező, több területen is jó adottságokat felmutatni képes közigazgatási egységek (nagyvárosok, esetleg országok) számára a differenciálatlan politika hozhat elönyöket, míg a kisebb települések a koncentrált politika követése révén juthatnak elönyökhöz.

Az utóbbi két megközelítés (a differenciált és a koncentrált szegmentációs politika) felveti a piac-szegmentáció gondolatát, amely a piacon beliul azon célcsoportok kijelölését foglalja magába, amelyeket érdemes és lehetséges a településre csábitani. Ez lehetővé teszi, hogy a későbbiek során az önkormányzat már csak ezekre a célcsoportokra koncentráljon, így biztosítsa a rendelkezésre álló erőforrások leghatékonyabb felhasználását és egyúttal növelje a marketingfolyamat sikerének a valószínüségét.

A piac-szegmentáció keretében az egyik legfontosabb vizsgálandó tényezỏ az egyes célcsoportoknak a termékhez való viszonya. Ennek megfelelően a piac résztvevőit elemezve elöször különbséget kell tenni az adott terméket már használók (,users"), illetve a potenciális fogyasztók („,non-users”) között (pl. egy adott településen müködö illetve a megcélzandó vállalatok), majd a terméket már használók kategóriáján belül a gyakori használók („heavy users”) illetve a ritka használók („light users”) között (pl. egy adott városi szolgáltatást rendszeresen illetve alkalomszerüen igénybe vevö lakos, vagy egy adott területet minden évben illetve tízévente egyszer meglátogató turista). A marketing tevékenység során az önkormányzatnak arra kell törekednie, hogy egyrészt a potenciális fogyasztókat átalakítsa ritka használókká, másrészt a ritka használókat gyakori használókká.

A piac-szegmentáció következő lépcsőfoka az ún. vásárló-haszon elemzés (,,buyerbenefit analysis") elvégzése. Ennek keretében (támaszkodva a település erỏs és gyenge pontjait feltáró vizsgálatok eredményeire) meg kell állapítani azokat a piaci szegmense- 
ket, amelyek számára a termék (ebben az esetben a település) olyan kézzel fogható hasznot tud nyújtani, amely felkelti az adott csoport érdeklődését. Ennek szellemében három fỏ szegmens különíthető el (lakosok, turisták, vállalkozók), de mindegyik csoporton belül további szegmentáció is elvégezhető.

A turisták csoportja többek között magába foglalja az üzleti és konferencia-turizmust, a barátok és rokonok meglátogatását, az osztálykirándulásokon részt vevő tanulókat, a hétvégi turizmust, az egy-két hetes üdülést stb.

A piac-szegmentáció későbbi szakaszaiban a már kiválasztott célcsoportokat kell megvizsgálni. Elemezni kell földrajzi elhelyezkedésüket, korukat, iskolai végzettségüket, jövedelmi viszonyaikat. Az így nyert adatok igen fontos bázist jelentenek a későbbi marketing tevékenység számára.

\section{Az önkormányzatok által követhetö marketingpolitika}

A SWOT-elemzés eredményeinek figyelembevétele, valamint a piac-szegmentáció és a termék ismerete alapján az önkormányzatok négy lehetséges marketingpolitika között választhatnak (3. ábra).

\section{3. ÁBRA}

Az önkormányzatok marketingpolitikájának négy típusa

(The four types of local government marketing policies)

\begin{tabular}{|l|l|l|}
\hline \multirow{2}{*}{} & \multicolumn{2}{|c|}{ A terület adottságainak } \\
\cline { 2 - 3 } & \multicolumn{1}{|c|}{ megtartása } & \multicolumn{1}{c|}{ fejlesztése } \\
\hline $\begin{array}{l}\text { Létező fogyasztók } \\
\text { Új fogyasztók }\end{array}$ & $\begin{array}{l}\text { konszolidációs politika } \\
\text { expanziós politika }\end{array}$ & $\begin{array}{l}\text { minőségfejlesztő politika } \\
\text { diverzifikációs politika }\end{array}$ \\
\hline
\end{tabular}

Forrás: Ashworth, G. J.-Voogd, H. (1988)

A konszolidációs politikát azon önkormányzatok folytatják, amelyek kiemelkedő adottságokkal és megfelelő számú fogyasztóval rendelkeznek, és a közeli jövőben nem kell különösebb társadalmi-gazdasági-szociális problémával szembenézniük. A minổségfejlesztő politika esetében az önkormányzatoknak (például egy új vetélytárs feltünése miatt) a létező fogyasztók megtartása érdekében is jelentős beruházásokat kell végrehajtaniuk (ez elsősorban az elavult adottságokkal rendelkező városok számára ajánlatos). A hollandiai Groningen városa például nemcsak a környék lakosságának, hanem a határ közelében élő németeknek is egyik fö bevásárlóközpontja. Ezen vásárlókör megtartása érdekében az önkormányzat jelentós beruházásokba kezdett: egyrészt a település főterének átalakítása során (az ún. Waagstraat-project keretében) új, luxuscikkeket árusitó üzleteket is kialakítanak. Másrészt a várost körulvevő autópálya mentén parkolókat hoztak létre, ahonnan a buszok igen alacsony áron szállítják a vásárolni szándékozókat a belvárosba. 
Az expanziós politika új fogyasztókat akar megnyerni a már létező kedvező adottságok számára (pl. jelentös történelmi emlékekkel, de viszonylag kevés látogatóval rendelkezö városok). A legambiciózusabb stratégia a diverzifikációs politika, amelynek keretében az önkormányzatok egyszerre törekednek az adottságok fejlesztésére, illetve új fogyasztók vonzására. Az 1970-es évek közepén a deindusztrializáció káros hatásaitól szenvedó Birmingham vezetỏi úgy döntöttek, kísérletet tesznek arra, hogy a város a jövőben az üzleti turizmus egyik központjává váljon, és ennek érdekében több területen is hozzáláttak az infrastruktúra fejlesztéséhez: 1976-ban felépült a Nemzeti Kiállítási Központ, majd 1991 áprilisában átadták a Nemzetközi Kongresszusi Központot. Ezzel párhuzamosan jelentős beruházásokat hajtottak végre a nemzetközi repülótéren és mind kapacitásában, mind minőségében javítottak a város szállodaállományán (Fretter, A. P. 1993).

\section{Az önkormányzatok reklámtevékenysége}

A városmarketing utolsó eleme a reklámtevékenység, amelyet két részre lehet osztani. Egyrészt az önkormányzatnak meg kell terveznie egy olyan arculatot illetve ezt megtestesitő üzenetet, amely képes meggyőzni az egyes célcsoportokat az adott terület elönyeiről, másrészt ezt az üzenetet el kell juttatnia a piac résztvevöihez.

Az összeállított üzenet tartalmával kapcsolatban több feltétel is létezik, amelyek teljesưlése a marketing tevékenység sikerének előfeltételét képezi (Kotler, P. et al. 1993):

- az üzenetnek igaznak kell lennie: ha az önkormányzat a valóságos helyzetnél szebb képet próbál meg magáról terjeszteni, igen nagy a csalódás esélye;

- az üzenetnek hihetőnek kell lennie: nem állhat túl messze a területröl kialakult benyomásoktól, érzelmektól;

- az üzenetnek egyszerünek kell lennie: ha a város túl sok üzenetet próbál meg terjeszteni, az zavarhoz vezethet;

- az üzenetnek vonzerővel kell rendelkeznie: meg kell magyaráznia, miért érdemes az adott településen élni, ott beruházni, az adott területet meglátogatni;

- az üzenetnek megkülönböztető jellegünek kell lennie: ki kell emelnie az adott települést a vetélytársak sorából.

A reklámanyagok tartalmának összeállítása során az önkormányzatnak több kérdésre is választ kell adnia. Döntenie kell az ,erös illetve gyenge stratégia” között (a kedvező benyomások további megerósítésére helyezi-e a hangsúlyt vagy a létezỏ negatív benyomások megszüntetésére törekszik), a meggyőzés-stratégia illetve az információközlés stratégia között (szemet gyönyörködtetỏ színes brosúrát alkalmaz, vagy részletes kiadványt állít össze a területtel kapcsolatos legfontosabb információkról) és arról, hogy a terület általános vagy speciális jellemvonásait próbálja-e meg elsösorban reklámozni.

Ezekben az esetekben a meghatározó tényezö a fogyasztónak a vásárlási folyamatban elfoglalt helye (4. ábra), és ez a tény többé-kevésbé befolyásolja az üzenet terjesztésének a módját is. 


\section{4. ÁBRA}

A fogyasztónak a vásárlási folyamatban elfoglalt helye és az alkalmazandó stratégia illetve kommunikációs eszközök közötti összefüggés

(The correlation of the place of the consumer in the shopping process, the strategy to be used and means of communication)

\begin{tabular}{|c|c|c|}
\hline $\begin{array}{l}\text { A vásárló helye a vásá rlási } \\
\text { folyamatban }\end{array}$ & Az alkálmazandó stratégia & $\begin{array}{c}\text { Az alkalmazandó } \\
\text { kommunikációs eszközōk }\end{array}$ \\
\hline az igény jelentkezése & \multirow{2}{*}{$\begin{array}{l}\text { általános jellemvonásck meg- } \\
\text { gyỏzés stratégia } \\
\text { erỏs stratégia }\end{array}$} & \multirow{6}{*}{$\begin{array}{l}\text { TV-, rádió-, újsághirdetés } \\
\text { kiállítások, vásárok } \\
\text { színes kiadványok személyes } \\
\text { levelek küldése } \\
\text { személyes tárgyalások }\end{array}$} \\
\hline információkeresés & & \\
\hline $\begin{array}{l}\text { az alternatívák } \\
\text { összehasonlítása }\end{array}$ & \multirow{4}{*}{$\begin{array}{l}\text { speciális jellemvonások } \\
\text { információközlés } \\
\text { gyenge stratégia }\end{array}$} & \\
\hline döntés & & \\
\hline vásárlás & & \\
\hline vásárlás utáni értékelés & & \\
\hline
\end{tabular}

Szerkesztette: Kozma G.

A kezdeti szakaszban (igény jelentkezése, az információ-keresés kezdeti periódusa) a legfontosabb feladat a piac szereplöi (akik még igen keveset tudnak az adott helyröl - pl. még soha nem hallottak róla, vagy tudják ugyan hol helyezkedik el, de nem ismerik semmilyen tulajdonságát) érdeklödésének a felkeltése. Rá kell vinni az adott helyet az emberek fejében meglévő térképre, el kell érni, hogy azt potenciális termékként vegyék figyelembe. Ebben a szakaszban az önkormányzat szempontjából célszerü az általános tulajdonságok hangsúlyozása az ún. „erős” stratégia alkalmazásával és a színes, szemet gyönyörködtetö kiadványok használata.

Ekkor ugyanis még nem érdemes speciális jellemvonásokat reklámozni és a gyenge stratégiát alkalmazni, mivel fennáll az a veszély, hogy ha később az emberek erre a helyre gondolnak, csak a negativ dolgokra fognak emlékezni. A színes brosúrák alkalmazása azért igen jelentős, mert ezek hozzájárulnak az illető hely másokétól eltérő profillal történó felruházásához.

A késóbbi szakaszokban (az információkeresés későbbi periódusai, az alternatívák öszszehasonlitása) lényegesen eltérő stratégiát kell folytatni. Ekkor már sokkal nagyobb figyelmet kell fordítani a speciális tulajdonságokra, részletes információk továbbítására (adatokkal kell meggyőzni a fogyasztót az adott hely előnyeiröl). Ekkor már a "gyenge” stratégia is alkalmazható, mivel ebben a fázisban a tagadás (törekvés a létező negatív érzelmek megszüntetésére) sokkal nagyobb figyelmet kelthet mint az állitás. 
Az üzenet tartalmának megtervezése során természetesen különbséget kell tenni az egyes célcsoportok között, és más témákat kell hangsúlyozni a üzleti élet szereplöinek, a turistáknak illetve a lakosoknak szánt reklámanyagokban.

\section{a) Az üzleti élet szereplöi mint célcsoport}

Az üzleti élet szereplöit két csoportra lehet osztani. Egyrészt a város vezetőségének törekednie kell a településen müködó vállalkozók megtartására, tevékenységïk támogatására és elismerésére. Ez azért igen fontos, mivel a virágzó helyi gazdaság a legjobb ajánlólevél a város számára, illetve a helyi viszonyokkal elégedett vállalkozó hatékonyabb propagandát tud kifejteni társai körében, mint a helyi önkormányzat. Az önkormányzat ezen a területen igen sokat tud tenni. Jó kapcsolatokat kell kialakítania a helyi cégek szervezeteivel (pl. gazdasági kamara), figyelembe kell vennie javaslataikat és kísérletet kell tennie a felmerült problémák orvoslására. Emellett törekednie kell arra is, hogy valamilyen formában (pl. egy évente kiosztásra kerülö dij keretében) elismerje a legjobb teljesítményt nyújtó vállalkozó munkáját.

Másrészt a helyi önkormányzatnak próbálkoznia kell üj vállalatok vonzásával is. A körưkben végzett reklámtevékenység során elsősorban két területre kell nagyobb figyelmet fordítania (Burgess, .J. A. 1982). Hangsúlyoznia kell mindazon gazdasági elömyöket, amelyek elérhetốek lesznek a településen letelepedô vállalatok számára. Ennek keretében az egyik igen fontos tényező a kedvezó fekvés kiemelése. Ez igen lényeges, mivel a vállalkozók körében az a tapasztalat létezik, hogy egy elszigetelt területre történö költözés versenyképtelenné teszi tevékenységüket (Gold, J. R. 1994). Ebből a szempontból a központi fekvés a legkedvezőbb, mivel ez azt a benyomást kelti, hogy az illetó vállalkozó bekerülhet a terület gazdasági vérkeringésébe. Azon helyek, amelyek elhelyezkedése minden kétséget kizárólag periférikus, ezt a fekvést úgy reklánozhatják, mint egy kaput a saját országuk, illetve egy másik ország testébe (pl. Finnország - egyedülálló kapcsolat Oroszország és a balti államok felé), valamint ki kell emelniük az illető ország központi régiójának rövid idön belül történö elérhetôségét (pl. az Amerikai Egyesült Államokban az elsörangú légi összeköttetést, Franciaországban a TGV elönyeit.)

Az önkormányzatoknak a reklámanyagokban hangsúlyozniuk kell a munkaerő megbizhatóságát és szakképzettségét. az irodaépületek és az építkezési korlátozásoktól mentes telkek óriási választékát stb. A település kedvező adottságainak illusztrálása céljából közzétehetnek egy meggyözỏ listát a már letelepedett nemzetközileg is híres vállalatokról. Hivatkozhatnak a cégek termelésében az odaköltözés után bekövetkezett növekedésre, és megkérhetik vezetőiket arra, hogy ök is fejezzék ki elégedettségüket az illető hely adottságaival kapcsolatban.

Az önkormányzatok emellett hivatkozhatnak az életminóség állandó javulására (pl. tágas és kényelmes bevásárlóközpontok, jó oktatási rendszer, kiváló kikapcsolódási lehetöségek, a környék egyedülálló szépsége). Ez igen lényeges, mivel a vállalkozókat meg kell győzni arról, hogy a városba költözés után életszínvonaluk nem fog csökkeni, söt ezen a területen még emelkedés is várható. 


\section{b) A lakosság mint célcsoport}

A reklámtevékenység során az önkormányzatnak különbséget kell tennie a potenciális lakosok (akiket a településre akarnak vonzani), illetve a már ott élók között. Az új lakosok csábitására irányuló törekvés nem ismeretlen jelenség: a múlt században az Amerikai Egyesült Államokban, a két világháború között pedig Nagy-Britanniában játszott igen fontos szerepet a területi politikában (Gold, J. R.-Gold, M. M. 1994, Ward, S. V. 1994), napjainkban tovább növekszik ezen tevékenység népszerüsége. A megcélzott csoportok közé tartoznak a fiatalabb, magasan képzett szellemi dolgozók (Brownill; S. 1994), illetve a nyugdíjasok (ez utóbbi szegmeıss elsỏsorban déli területeken fekvő régiókban játszik fontos szerepet - pl. Florida, Kalifornia). A reklámtevékenység során az önkormányzatnak elsösorban azokra az adottságokra kell koncentrálnia, amelyek ezen célcsoportok szempontjából nagyobb jelentöséggel bírnak (pl. luxuslakások, kiváló kikapcsolódási lehetőségek, kedvezỏ időjárás, alacsony megélhetési költségek, jó orvosi ellátás).

Kedvezö benyomások kialakítása a településen élö lakosság körében igen fontos feladat, mivel csak ez, illetve ennek következményei (pl. a lakosok magabiztossága) képes megteremteni a város múködésének az alapjait. A településével elégedetlen népesség elvándorlása ( $\mathrm{pl}$. az értelmiség elköltözése) az egész szellemi életet veszélybe sodorhatja, azon országokban pedig, ahol a városi költségvetés bevételei között a személyi jövedelemadó fontos szerepet játszik, a gazdagabb rétegek távozása komoly problémákat idézhet elö a kiadások finanszírozásában (Probáld K. 1994).

A lakosság azonban speciális helyzetben van, mivel egyrészt a lakólelyével szemben igen különbözö elvárásokkal rendelkezik, másrészt első kézböl tesz szert benyomásokra, tapasztalatokra. Ha az önkormányzat a lakosság körében pozitív képet akar kialakitani a városról (és ezen keresztül saját munkájáról), akkor elsősorban az ún. „ubiquitas” jellemvonásokra kell koncentrálnia (pl. kedvezó vásárlási lehetöségek, jó közlekedési hálózat). Ezen túl olyan programokat kell szerveznie, amelyek erősítik a lakosság öntudatát. Éreztetnie kell a helyi lakossággal, hogy kíváncsi a véleményére (a hollandiai Groningen városában például az új rendezési terv elkészitése során az egyes területekre több alternatív javaslatot is kidolgoztak, az ezek közötti végleges döntés során figyelembe vették a lakosság véleményét).

c) A turisták mint célcsoport

A turisták mint fogyasztók két szenıpontból is sajátos helyzetben vannak. Egyrészt a terület elözetes meglátogatása, anely a házvásállás, vállalatalapítás esetében a keresési folyamat szerves részét képezi, nem végezhetö el a jövöbeli turisták által. Másrészt a turisták illetve ismeröseik korábbi tapasztalatai csak szerény elörejelzöi az úttal való késóbbi megelégedettségnek, mivel a sikert meghatározó viszonyok speciálisan idöre és helyre jellemzőek. Így a potenciális turisták korlátozottan rendelkezésre álló információk alapján kénytelenek választani az üdülőhelyek közül. Ennek következtében a reklámtevékenység során az ôszinteség és a túlzás közötti dilemma különösen élesen vetödik fel a turizmus esetében. A legtöbb turistaügynökség tevékenységében megfigyelhetö egy enyhe túlzás, amelyet egy bizonyos fokig a turisták is elfogadnak, de a reklámtevékenység által 
keltett elvárás és a tényleges élmények közötti túl széles rés üdülés utáni reklamációkat okozhat.

A reklámanyagokban elsősorban a terület azon tulajdonságait kell hangsúlyozni, amelyek képesek megkülönböztetó jelleget adni az adott helynck, kiemelni ôt a versenytársak sorából. Emellett azonban figyelembe kell venni az egyes célcsoportok földrajzi elhelyezkedését is. Ez azt jelenti, hogy ablakon kidobott pénz és idö az embereket meggyőzni bizonyos területek meglátogatásáról, ha ugyanazt az élményt eredeti lakóhelyükhöz közelebb is megkaphatják (Dilley, R. S. 1986).

$\mathrm{Az}$ üzenet terjesztésével kapcsolatban az önkormányzatnak több kérdésben is állást kell foglalnia. Egyrészt ki kell választania az alkalmazandó tömegkommunikációs eszközt (rádió-, televizió-, újsághirdetés, hirdetötábla, különbözö brosúrák). A döntés során az üzenet jellege, az egyes eszközök költsége (mint nem elhanyagolható szempontok) mellett az egyik legfontosabb meghatározó tényezỏ a vásárlónak a vásállási folyamatban elfoglalt helye (4. ábra). A kezdeti szakasz céljaira (figyelem felkeltése az adott hely iránt) a rádió-, televizió- és újsághirdetések a legalkalmasabbak, de ezek mellett igénybe lehet venni a kiformálódott testvérvárosi kapesolatokat, a különbözỏ kiállitásokat és vásárokat. Ezzel szemben a későbbi periódus fö célkitüzése (kedvezö pozíció biztositása az alternatívák összehasonlitása során) elsösorban részletes információkat tartalınazó kiadványok segítségével érhetó el.

A legfontosabb dolog azonban, hogy a végső döntés egy sokkal személyesebb forrás általi megerösítést igényel, ami lehet egy látogatás az adott területen ( $\mathrm{pl}$. konferencia vagy kiállitás keretében), vagy ha ez nem lehetséges, akkor ismerösök beszámolója, hivatásos közvetítók tanácsa (Ashworth, G. J.-Voogd, H. 1990).

Másrészt az egyes kategóriákon belül ki kell választani azt a speciális eszközt, amely a kívánt eredmény elérését a leggazdaságosabban tudja biztosítani. Ennek során figyelembe kell venni az illetỏ orgánum presztizsét (az adott célcsoport mennyire fogadja el hitelesnek, valóságos adatot közlőnek az illetỏ médiumot), földrajzi elterjedtségét (pl. újsághirdetés helyi, országos vagy nemzetközi napilapban).

Harmadrészt dönteni kell a reklámtevékenység időbeli ütemezését illetỏen (pl. folyamatos reklámozás vagy egy rövid időszakra irányuló tevékenység), és rendszeresen ellenörizni kell a rekláıntevékenység hatékonyságát.

\section{Összegzés}

A Nyugat-Európában és Észak-Amerikában egyre nagyobb népszerüségre szert tevő városmarketing, amely mind több geográfus érdeklődését kelti fel, nagy lehetőséget, de egyúttal igen kemény kihívást is jelent a hazai kutatók szánára. Véleményem szerint kettős feladat áll előttük. Egyfelöl közvetíteniük kell a fejlettebb országokban felhalmozódott tudást az önkormányzatok felé (ezen a területen már vannak biztató jelek), másfelöl négy-öt év múlva - fellıasználva az összegyült tapasztalatokat - kisérletet kell tenniük egy szintézisszerủ munka elvégzésére. 


\section{Irodalom}

Ashworth, G. J.-Voogd, H. (1988) Marketıng the city: concepts, process and Dutch applications. Town Planning Review. 59. 1. 65-79. o

Ashworth, G. J.--Voogd, H.(1990) Selling the city. Belhaven, London.

Ashworth. G. J.-Voogd, H.(1994a) Marketing of tourism places: what are we doing. Journal of International Consumer Marketing, 6. 3/4. 5-19.0.

Asliworth, G. J.-Voogd, H. (1994b) Marketing and place promotion. In: (ed.: Gold, J. R.-Ward S. V.) Place promotion: the use of publicity and marketing to sell towns and regions. John Wiley and Sons Ltd. Chichester, 39-52. 0

Áts Z (I994) Önkormányzatok marketing-konmunikációja. Marketing, 1. 59-61. o.

Bark. M.--l larrop, K. (1994) Selling the industrial town: identity, image and illusion. ln (ed.: Gold, J. R.-Ward, S. V.) Place promotion: the use of publicity and marketing to sell towns and regions. Jolnn Wiley and Sons Ltd.. Chichester, 93-115. o.

Bartels, C. P. A.-Timner, M. (1987) City marketing: instruments and effects. Paper to be presented at the European congress of the Regional Science Association.

Berg. L. van den-Klaassen. L. H.-Meer, J. van den(1990) Marketing metropolitan regions. Erasmus University, European Institute for Comparative Urban Research. Rotterdam.

Borchert. J. G. (1989) Citymarketing - eine neue Domane der Angewandten Giengraphic. Stadt und Kulturraum. Bochumer Geographischen, Arbeiten, 50. 79-87, o.

Brownill, S. (1994) Selling the inner city: regeneration and place marketing in London's Docklands. In: (ed.: Gold, I. R.-Ward, S. V.) Place promotion: the use of publicity and marketing to sell towns and regions. John Wiley and Sons Lid., (Chichester, 133-153. o

Burgess, J. A. (1982) Selling places: environmental images for the executive. Regional Studies, 16. 1. 1-17. o.

Burgess, J. A.-Wood. P. (1988) Decoding Docklands: place advertising and decision-making strategies of the stnall firms. In (ed.: Eyles, J.-Smith, D. M.) Qualitutive methods in human geography. Polity Press. London. 94-1I8. o.

Clarke, A. (1986) Local authority plamers or frustrated tourism marketeers. The Plamer. 72. 5. 23-27 o

Dilley, R. S. (1986) Tourist brochures and tourist images. The Canadian Geographers, 30. 1. 59-65. o.

Frelter, A. D. (1993) Place-marketing: a local authority perspective. In: (ed.: Philo, C.-Kearns, K.) Selling Places: the city as cultural capital. Pergamon. London, 163-175. o.

Fülöp G. (1994) Arculattervezet Budapesinek. Reklángaźlaság. 4. 1-4. o.

Gold I. R.-Gold, M. M. (1994)..Honte at 1 ast!": building socicties, home ownership and the imagery of Englisly suburban promotion in the interwar years. In: (ed.: Gold. J. R.-Ward, S.V.) Place promotion: the use of publicity and marketing to sell towns and regions. John Wilcy and Sons Lid., Chichester, 75-93.

Gold, I. R. (1994) Locating the message: place promotion as image conmunication. In: (ed: Gold. J. R.-Ward. $S$. V.) Hace promotion: the use of publicity and marketing to sell towns and regions. John Wiley and Sons Lid. Chichester. 19-39), 0.

Goodall. B. (1988) How tourists choose their holidays: an inalytical framework. In: (ed.: Goodall, B. Ashwurth. G. J.) Marketing in the tourism industry. Croom Helm. Beckemhan. I-18. o.

Karski, A. (I990) Urban tourism - a key to urban regeneration? The Planner, 76. 13. April 6. 15-17. o.

Kotler, P.-Haider, D. H.-Rein, I. (1993) Morketing places: attracting mvesiment, undustry and tourism to cuttes. states and nations. Macmillan. New York.

Law. C. M. (1992) Urban tourism and its contribution to economic regeneration. Urban Studies. 29. 3/4 599618.0

Lim. H. (1993) Cultural strategles for revitalizing the city: a review and evaluation. Regional Studies. 27.6 $589-595,0$

Madsen. H. (1992) Place-marketing in Liverpool: a review. Imernational Journal of Urban and Regional Research. 16. 633-6.40.0

Pirkinson, M. (1991) The rise of entrepreneurial European city: strategic responses to economic changes in the 1980s. Ekistics, 350-351. Seplember/October-November/December, 299-307. o.

Philo, C.-Kcarns, K. (ed.) (I993) Selling places: the city as cultural capital Pergamon, London.

Paddison. R. (1992) City marketing image reconstruction and urban regeneration. Urban Studies, 30, 2. 339350.0 .

Probáld K. (1994) Kommunikáció a településfejlesztés szolgálatában (Vórosmarketing). Szakdolgozat. BKE: Külgazdasági Tanszćk, Budapest. 
Schınidt, L. (1994) Önkormányzat és marketing. Markeling, 3. 168-172. o.

Shott, J. R.-Benton, L. M.-Luce. W. B.-Walton, J. (1993) Reconstructing the image of an industrial city. Annals of the Association of American Geographers, 83, 2. 207-224, o.

Ward. S. V. (1994) Time and place: key thentes in place promotion in the USA. Canada and Britain since 1870. In (ed.: Gold, J. R.-Ward. S. V.) Place promotion: the use of publicity and marketing to sell towns and regions. John Wiley and Sons Ltd.. Chichester. 53-75. o.

\section{CITY MARKETING AS ONE OF THE POSSIBLE TOOLS OF LOCAL ECONOMIC DEVELOPMENT}

\section{GÁBOR KOZMA}

City marketing - as a new, market-oriented approach of urban policy - has been focused on in the West European and North American big cities since the second half of the 1970s. The self governments of the Central European countries have paid greater and greater attention to this topic since the systemic change, too. In the background of the special interest in city marketing, we can see those European and American changes (e.g. the growth of the service sector, the development of the transport and information technology, the failure of the formerly applied regional-planning methods) that have significantly weakened the economic bases of the towns. This made the self governments realise that they had to play a much more initiative role in shaping the future of their towns: It is not enough to control development but it has to be efficiently supported.

The author attempts to introduce the most important characteristics of this new type of urban policy. First he seeks the answer to the question of where the differences between city marketing and traditional marketing are. In his opinion the differences appear especially with respect to the ,product to be marketed": Towns have special features (e. g. they are much more complex and much less flexible than traditional products, they are situated in a spatial context), which factor has an influence on the whole marketing process.

In the second part of the essay the author deals with the specific parts of city marketing. stressing that the neglect of any element can endanger the success of the whole process. The first very important task is the survey of the inner and outer environment of the settlement, as a result of which the self government can obtain a broad picture of the situation of the town. Simultaneously, the self government has to try to develop the endowments, which contains four fields. It has to provide the infrastructural bases of further development, also, it has to create a suitable co-opearation between the organs involved in the marketing activity. It has to establish an attractive image of the town as well as to create attractions that can attract visitors to the town.

The following important element of city marketing is market segmentation, which means the choice of the target groups that the self government wants to attract. During 
this process, the relationship of the specific target groups to the settlement has to be analysed and those market segments have to be specified for which the town can offer advantages that awake the interest of the given group.

In the last step the self government has to appear in the market and it has to strive, using different means, to create a favourable image of itself. In the framework of this, it has to plan, on the one hand, a face and a message carrying it that can convince people of the advantages of the given region, on the other hand, this message has to be transferred to the specific market segments. During this process the different needs of the certain target groups (e.g. tourists, actors of business life) have to be taken into consideration and the self government has to find where these groups (as consumers) are in the purchasing process.

\section{Translated by Zoltán Raffay}

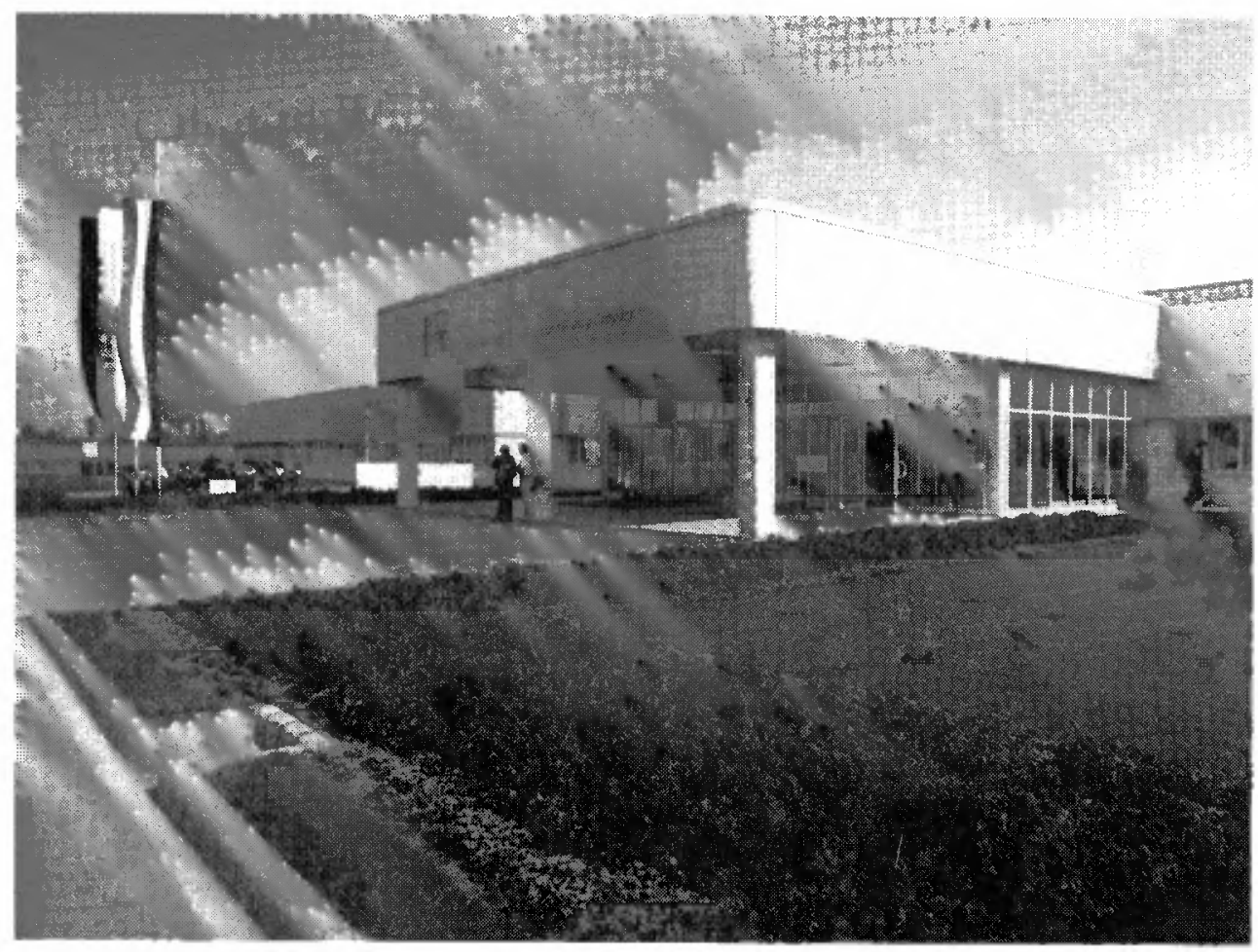

A dinamizálódó Székesfehérvár - A Philips gyár (MTI FOTÓ - Mónos Gábor) 